\title{
PATTERN AND PROCESS: EVOLUTION OF TROGLOMORPHY IN THE CAVE-PLANTHOPPERS OF AUSTRALIA AND HAWAI'I - PRELIMINARY OBSERVATIONS (INSECTA: HEMIPTERA: FULGOROMORPHA: CIXIIDAE)
}

\author{
VZOREC IN PROCES: EVOLUCIJA TROGLOMORFNOSTI \\ PRI JAMSKIH MREŽEKRILNIH ŠKRŽATKIH IZ AVSTRALIJE \\ IN HAVAJEV - PRELIMINARNE UGOTOVITVE (INSECTA: \\ HEMIPTERA: FULGOROMORPHA: CIXIIDAE)
}

\author{
Andreas WESSEL ${ }^{1}$, Petra ERBE ${ }^{1,2}$ \& Hannelore $\mathrm{HOCH}^{1}$
}

\begin{abstract}
UDC 591.542(94+739,9)

Andreas Wessel, Petra Erbe \& Hannelore Hoch: Pattern and process: Evolution of troglomorphy in the cave-planthoppers of Australia and Hawai'i - Preliminary observations (Insecta: Hemiptera: Fulgoromorpha: Cixiidae)

The evolution of troglobites comprises three distinct problems: cave colonization by an epigean ancestor, the evolution of troglomorphies, and intra-cave speciation. The study of cave-dwelling planthoppers has contributed much to our understanding of troglobite evolution and provides useful model systems to test various aspects of the theoretic framework developed in recent years. Most promising in this respect are taxa with several closely related but independently evolved troglobiontic lineages, such as on the Canary Islands, in Queensland/Australia and on the Hawaiian Archipelago. Closely related species often occur in caves with comparable ecological parameters yet differ in their age. Here we use comparative age estimates for Australian and Hawaiian cave cixiids to assess the dynamics of reductive evolutionary trends (evolution of troglomorphy) in these taxa and cave planthoppers in general. We show that the degree of troglomorphy is not correlated with the age of cave lineages. Morphological alteration may not be used to draw conclusions about the phylogenetic age of cave organisms, and hypotheses based on such assumptions should be tested in light of these findings.

Key words: adaptive shift, cave adaptation, climatic relict, founder effect, reductive evolutionary trends, troglobites, troglomorphies.
\end{abstract}

Izvleček

UDK 591.542(94+739,9)

Andreas Wessel, Petra Erbe \& Hannelore Hoch: Vzorec in proces: Evolucija troglomorfnosti pri jamskih mrežekrilnih škržatkih iz Avstralije in Havajev Preliminarne ugotovitve (Insecta: Hemiptera: Fulgoromorpha: Cixidae)

Evolucija troglobiontov zajema tri značilne korake: kolonizacija jame s površinskim prednikom, razvoj troglomorfnosti ter podzemeljska speciacija. Študija podzemeljskih mrežekrilnih škržatkov je prispevala veliko k našemu razumevanju evolucije troglobiontov in hkrati predstavlja uporaben modelni sistem za testiranje različnih teoretičnih pristopov, ki so bili razviti $\mathrm{v}$ zadnjih letih. V tem pogledu so najobetavnejši tisti taksoni, ki so si sicer sorodni, toda pripadajo evolucijsko neodvisnim troglobiontskimi linijami, kot so npr. tisti na Kanarskih otokih, $\mathrm{v}$ državi Queensland (Avstralija) in na havajskem arhipelagu. Bližje sorodne vrste se $\mathrm{v}$ jamah pogosto pojavijo $\mathrm{v}$ primerljivih ekoloških pogojih, vendar se razlikujejo v starosti. Za ugotavljanje dinamike trendov redukcijske evolucije (evolucija troglomorfizmov) teh taksonov in jamskih škržatkov na splošno, smo v prispevku uporabili ocene primerjalnih starosti za avstralske in havajske jamske škržatke. Ugotavljamo, da stopnja troglomorfnosti ni v korelaciji s starostjo jamskih linij. Zgolj morfološke spremembe pri organizmih se ne bi smele uporabljati za prikazovanje filogenetske starosti jamskih organizmov. Hipoteze, ki temeljijo na takšnih predpostavkah, bi morale biti preverejene v luči pričujočih ugotovitev.

Ključne besede: prilagoditveni premik, prilagoditve na podzemlje, klimatski relikt, učinek osnovatelja, redukcijski evolucijski trendi, troglobiti, troglomorfizmi.

\footnotetext{
${ }^{1}$ Museum für Naturkunde der Humboldt-Universität zu Berlin, Biosystematics Research Group, Invalidenstrasse 43, D-10115 Berlin, Germany; e-mail: andreas.wessel@museum.hu-berlin.de

${ }^{2}$ Chiang Mai University, The Uplands Program, Faculty of Agriculture, Chiang Mai, Thailand

Received/Prejeto: 30.01 .2007
} 


\section{INTRODUCTION}

The origin of troglobites has fascinated evolutionary biologists since Darwin remarked on their curious and strong modification (1859: 177-178). He did not provide a 'Darwinistic' explanation for their evolution ${ }^{1}$, however, this was subsequently supplied by August Weismann $(1886)^{2}$.

Troglobite evolution, i.e. the process leading to different, sometimes closely related species, which are highly adapted to life in subterranean spaces, comprises three somewhat independent phenomena and problems: (i) initial cladogenesis of a cave species, or the origin of a cave-dwelling bio-species from an epigean ancestor, which is basically the problem of isolation or rather (spatial) separation of a cave population from its epigean relatives; (ii) subsequent anagenetic transformation, which comprises the dynamics and driving forces of cave adaptation, the often so-called regressive evolution or reductive evolutionary trend, and, in some cases, (iii) subterranean (intra-cave) radiation.

\section{RELICTS OR EXPLORERS?}

A widely accepted concept aiming to explain the speciation event giving rise to a cave-dwelling and reproductively isolated bio-species, was developed by Thomas Barr in the 1960s, commonly known as the Climatic Relict Hypothesis (CRH):

1 "As it is difficult to imagine that eyes, though useless, could be in any way injurious to animals living in darkness, I attribute their loss wholly to disuse." (Darwin 1859: 177)

2 „As soon as such a cave immigrant has developed the ability to obtain food without the help of eyes a reduction of the eyes must commence, since as soon as the same are no longer neces-sary for the animals' existence, they are not influenced anymore by natural selection, because now it does not matter whether the eyes are a little worse or a little better. Now, no more selec-tion will take place between individuals with better and those with worse eyes, but both will have an equal chance to be preserved and reproduce. Individuals with better and those with worse eyes will cross from now on, and the result can only be a general degradation of the eyes. Pos-sibly this is helped by the circumstance that smaller and stunted eyes can even present an ad-vantage, since this allows other organs such as sensory and olfactory organs, which are more important for the animal now, to develop more strongly. Even without such effect, though, the lack of natural selection maintaining the eye's high level of organization will necessarily lead to its degradation, slowly or even very slowly, especially at the beginning of this process, but in-exorably." (Translated from the German; Weismann 1886: 16-17)
"Troglobites have evolved from colonies of troglophiles which became isolated in caves through extinction of surface populations of the troglophiles" (Barr 1968: 96).

According to Barr, the evolution of troglobites is a two-step process: at first, it involves a preliminary, troglophilic stage without apparent troglomorphies or a disruption of geneflow between cave-dwelling and epigean populations. Following this initial cave colonization, the cave-dwellers become geographically separated, and thus genetically isolated, due to the extinction of parental epigean populations (supposedly caused by climatic change), at least in the region of the cave. Over time, reproductive isolation will inevitably follow as a side effect of genetic change by drift and natural selection (Barr 1968). Support and evidence for this concept was gained from the observed relict distribution of most troglobites known at that time, which were almost exclusively confined to temperate regions. Glaciation during the ice ages was suggested as the most important factor for the change of surface conditions (Barr 1968, Sbordoni 1982, Barr \& Holsinger 1985).

This hypothesis remained without alternatives until the early 1970s, when Francis G. Howarth discovered the Hawaiian cave ecosystems (Howarth 1972). The lava tubes host, among other taxa, highly troglomorphic planthoppers that are parapatrically distributed with respect to their close epigean relatives, which are still extant, i.e. they are non-relictual troglobites. Consequently, Howarth $(1981,1986,1987)$ formulated the Adaptive Shift Hypothesis (ASH):

"[...] potential food resource provides the driving force for the [...] evolution of cave species. Troglomorphic populations [...] evolve from pre-adapted habitual accidentals which [...] establish temporary populations in marginal underground habitats. Once an adaptive shift occurs, allowing a reproducing population to establish itself underground, then it is both the effects of strong new selection pressures and the release from previously strong selection pressures that bring about [...] troglomorphy" (Howarth 1986: 155).

While the exploitation of a large new habitat with new food resources may be the driving force in the evolution of troglobites according to the ASH, a major challenge for survival underground is probably the ability to locate mates and reproduce in the dark. A change in mating behaviour might thus have been the most important adaptive shift necessary for a successful colonization of caves, and would almost inevitably lead to reproductive isolation of the incipient cavernicolous species. The Hawaiian cave planthoppers provide a striking example for 
this process, and consequently played a pivotal role in the formation of the Adaptive Shift Hypothesis (Howarth 1986, Howarth \& Hoch 2005).

A principal acceptance of the ASH does not necessarily invalidate the $\mathrm{CRH}$, especially not in cases where the preconditions for the $\mathrm{CRH}$ are met, i.e. cave taxa displaying a relict distribution. However, a relict distribution observed today is not sufficient evidence to unconditionally accept the $\mathrm{CRH}$, given the alternative present in the $\mathrm{ASH}^{3}$. The predictions arising from both hypotheses must be tested for every single system. For the CRH, we expect the closest epigean relatives at least to be allopatrically distributed compared to the cave species, while the ASH predicts a parapatric distribution of cave and epigean species, which are necessarily sistergroups (adelphotaxa). Conclusive evidence for a decision between both hypotheses may be gained from a well-founded phylogeny in conjunction with a sound knowledge of the geographic distribution of both cave and epigean taxa. The last requirement is often problematic, though, as the sampling of epigean relatives for some cave species is frequently insufficient. For some groups no epigean relatives are known at all, and it is only through intensive, directed search efforts that this obstacle may be overcome (see e.g. Stone 2004).

\section{REDUCTIVE EVOLUTIONARY TRENDS}

Once a population has shifted towards a permanently cavernicolous mode of living, the second problem of troglobite evolution - subsequent anagenetic transformation - arises. A basic assumption since Weismann (1886) has been a correlation between the degree of troglomorphy of a taxon and its residence time in caves. Cave adaptation is accordingly described as an orthogenetic, time-dependent process, which is an overall slow, gradual adaptation towards a stage of 'absolute troglomorphy'; see e.g. Wilkens (1986), for review see Barr (1968) and Howarth

\footnotetext{
3 "The evidence suggests that troglobites evolve from preadapted habitual visitors or accidentals in the cave rather than from well-adapted troglophiles. The former group requires an adaptive shift in order to fully exploit the cave resources. This adaptive shift may lead to the evolution of a troglobitic lifestyle. Well-adapted troglophiles on the other hand tend to remain opportunistic exploiters of the cave environment. Some temperate troglobites may fit the scenario of isolation by changing climates (Barr, 1968). However, many species including those in the tropics probably do not. I postulate that adaptive shifts led to the colonization of caves and evolution of troglobites, including most of those in temperate caves, but that the complex geological history of the continents including glaciations has obscured the early history and obfuscated the earlier distribution and the evolution of troglobites there." (Howarth 1981: 540)
}

(1987). Traditional explanations for the mechanisms of this process includes (i) the accumulation of neutral mutations, (ii) pleiotropic effects, and (iii) natural selection for energy economy (Sket 1986, Culver 1982). Both the CRH (Barr 1968) and ASH (Howarth 1986), however, contain some notion of a founder effect: Barr with an explicit quotation of Mayr's genetic revolution (Mayr 1954) and Howarth with reference to the Carson model of founder effects (Carson 1968, 1975).

The process of cave adaptation is influenced by several parameters - such as availability of food, population density, microclimate of the caves and other biotic and abiotic factors of the cave ecosystem - , which make comparisons even between closely-related species exceedingly difficult, and generalisations even more so. An excellent opportunity to test the assumption of gradual and increased troglomorphy over time may nevertheless be found in radiations of cave-dwelling planthoppers inhabiting caves of different age.

\section{CAVE-ADAPTATION IN PLANTHOPPERS}

Studies during the last three decades have revealed numerous cases of evolution of cave-adapted planthoppers in tropical and subtropical caves. Among the Fulgoromorpha, 53 cave-dwelling species have been described from many parts of the world, four-fifth of them cixiids including the Australian taxa Solonaima and Undarana and the Hawai'ian Oliarus species (Hoch 1994, Hoch \& Wessel 2006).

The adaptation to similar environments in cave planthoppers has led to the evolution of a very similar external morphology in different parts of the world and represents a striking example of parallel evolution. The morphological modifications of cave planthoppers are characterized by reductive evolutionary trends, as in most obligately cavernicolous animals. The degree of adaptation to a subterranean life varies greatly, primarily depending on their habitat in the cave or soil (Fig. 1). Most conspicuous are the reduction and loss of compound eyes and ocelli, tegmina, wings and bodily pigment. It has also been suggested that apparently non-troglomorphic characters have an increased adaptive value in the underground environment, such as e.g. the specialized spine configurations of hind tibiae and tarsi, which may possibly enhance walking on wet or rocky surfaces (Hoch \& Howarth 1989a, 1989b, Hoch 2002).

The closest epigean relatives of cavernicolous Fulgoromorpha species all have immature stages living close to the soil, e.g. under the dead bark of rotting logs, in leaf litter or moss, or even within the soil, feeding on roots or perhaps on fungi (Remane \& Hoch 1988). This mode of life has been considered an ecological pre-adaptation 


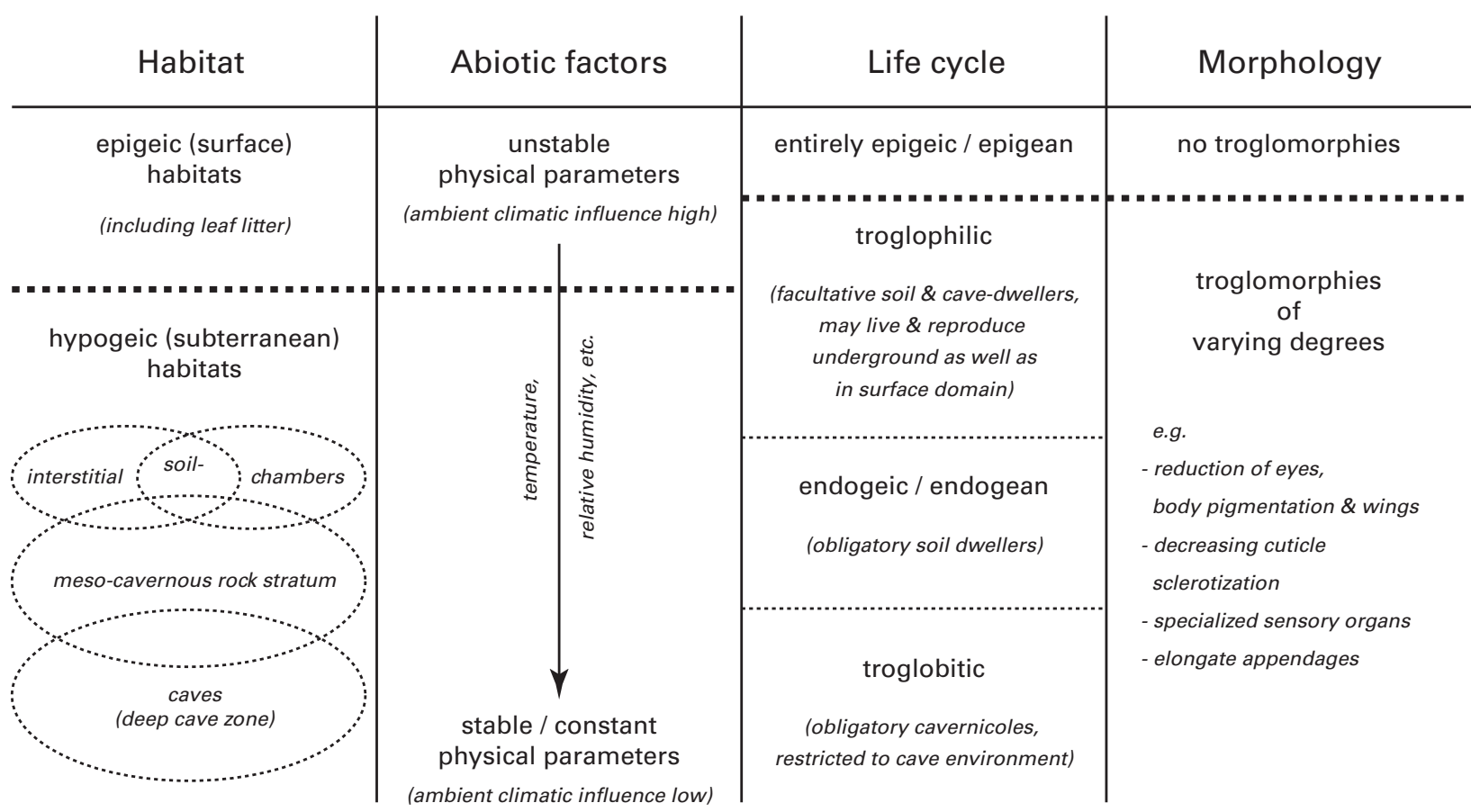

Fig. 1: Terminology of interdependence between physical parameters of the habitat and organismic adaptations (From Hoch et al. 2006).

to a later switch to a permanent (adult) life underground (Hoch 2002, Howarth \& Hoch 2005).

\section{CAVE-PLANTHOPPERS OF AUSTRALIA AND HAWAI'I}

In Australia, closely related Solonaima and Undarana species have colonized old karst caves as well as younger lava tube systems. The four epigean Undarana species occur in the (rain)forest at the south of Queensland's east coast, while the two cave-dwelling species (U. rosella, Bayliss \& Pinwills cave, Undara lava tube; U. collina, Collins cave) inhabit the lava caves of the McBride Formation in the dry grasslands westward of the Great Dividing Range (Hoch \& Howarth 1989a). The epigean Solonaima species can be found all along the east coast (rain)forest, while the cave species inhabit lava tubes within the McBride Formation, too (S. baylissa, sympatric with U. rosella), as well as karst caves of the Chillagoe Karst Towers (S. pholetor, S. stonei, S. halos, S. irvini) and Mount Mulgrave (S. sullivani) (Hoch \& Howarth 1989b). Thus, epigean and cavernicolous species of both Australian genera show an allopatric distribution.

On the Hawaiian islands the cave-dwelling species of the endemic, monophyletic Oliarus clade represent independent cave colonizations on islands of different age. With about 80 described epigean taxa (species and subspecies), Oliarus is the most speciose planthopper genus on the Hawaiian islands (Zimmerman 1948, Asche 1997).
Based on morphological data, this diversity has been hypothesized to stem from a single colonization event (Asche 1997, Hoch \& Howarth 1993). The first cave-dwelling species of the genus, Oliarus polyphemus Fennah, 1973 and Oliarus priola Fennah, 1973 (Fennah 1973) were discovered by Howarth (1972) on Hawai'i Island and Maui where they are endemic. Later, five more troglobitic taxa were discovered on the archipelago (Hoch \& Howarth 1999). The seven cave-dwelling species owe their origin to several independent colonization events on three islands; on Molokai, one adaptive shift (O. kalaupapae); on Maui, three adaptive shifts (O. priola, O. gagnei, O. waikau); on Hawai'i Island, at least three adaptive shifts (O. polyphemus, O. lorettae, O. makaiki) (Hoch \& Howarth 1999). The closely related epigean species of all cavernicolous Oliarus taxa occur parapatrically at the surface.

Both the Australian and the Hawaiian cave species complexes exhibit different degrees of troglomorphy. Figure 2 shows the heads of six Australian Solonaima, one epigean (1), three facultative cavernicolous (2-4), and two obligate cavernicolous species $(5,6)$. Figure 3 depicts the habitus of six Hawai'ian Oliarus species, one epigean relative on the left (note the different scale), and five troglobitic species. The varying degree of eye reduction is clearly visible; two of the Hawaiian species even show a complete loss of eyes. The same pattern is seen in wing reduction.

The time factor is crucial for assessing the dynamics of troglobite evolution. Unfortunately, though, it is 


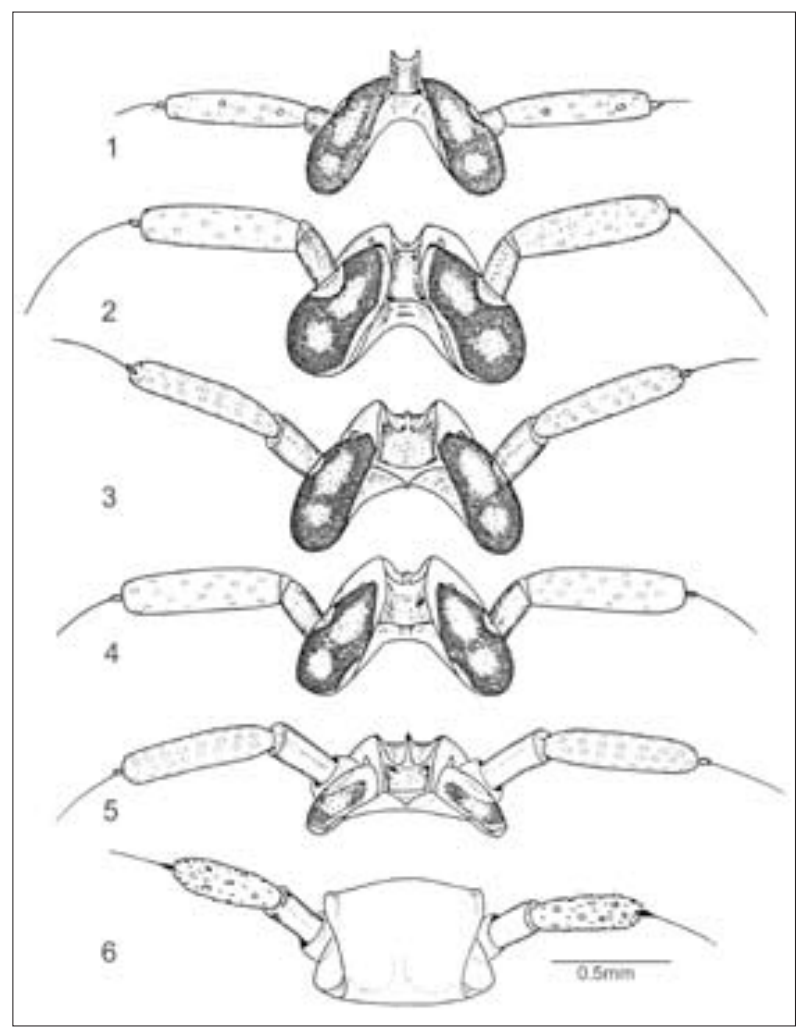

Fig. 2: Australian Solonaima species, heads, dorsal view. 1, S. solonaima (epigean); 2. S. sullivani; 3, S. pholetor; 4, S. stonei; 5, S. irvini; 6, S. baylissa. (From Hoch \& Howarth 1989b).

rarely possible to obtain direct estimates of the age of the cave lineages. Rather, the maximum age of the habitat is usually employed - at least if an active colonization of caves sensu Howarth is assumed - , or even just the maximum age of the underlying geological structure. By these measures, the maximum age for the troglobitic Oliarus lineages on Hawai'i is the age of the islands: 1.8 myr for Molokai, 1.3 myr for Maui, and less than 400,000 y for Hawai'i Island.
In the case of the Australian troglobitic cave planthoppers, the situation is even more complex. At first sight their distribution fits the Climatic Relict Model sensu Barr very well assuming a late Miocene desertification, i.e. replacement of the rain forest by dry savannah or grassland east of the Great Dividing Range (see Kemp 1978, Truswell 1990). While not per se refuting the relict hypothesis, we do not exclude the possibility of adaptive shifts for the Australian cave planthoppers as well. In that case, Australian cave taxa may be much older than hitherto assumed. Also, the late Miocene climatic change is not necessarily be regarded as the sole reference point for the calculation of the maximum age of the Australian cave planthoppers. What could matter instead is the availability of the caves as a suitable novel habitat.

The limestone of the Chillagoe Tower Karst and Mitchell-Palmer Karst are presumably of Silurian origin, and the current main caves were formed by phreatic solution during the last 5-10 million years (Ford 1978, Jennings 1982, Pearson 1982). Remnant older passages and solution breccias near the tops of many towers indicate the existence of caves since the area was uplifted and the limestone was exposed in the mid-Tertiary about 20-25 million years ago (Howarth 1988).

The much younger Undara lava flow (190,000 years old) covers portions of older flows within the McBride Formation (Atkinson et al., 1976), some of which may date back from the Pliocene, i.e. more than 2.5 million years ago (Best 1983). The cave animals could have migrated through the mesocavernous systeme into young basalt and colonized new caves in each flow in succession.

"The troglobitic species could be, and probably are, older than the age of their caves" (Howarth 1988).

\section{PHYLOGENETIC AGE AND TROGLOMORPHY}

Against this background we here attempt to assess the problem of the dynamics of reductive evolutionary

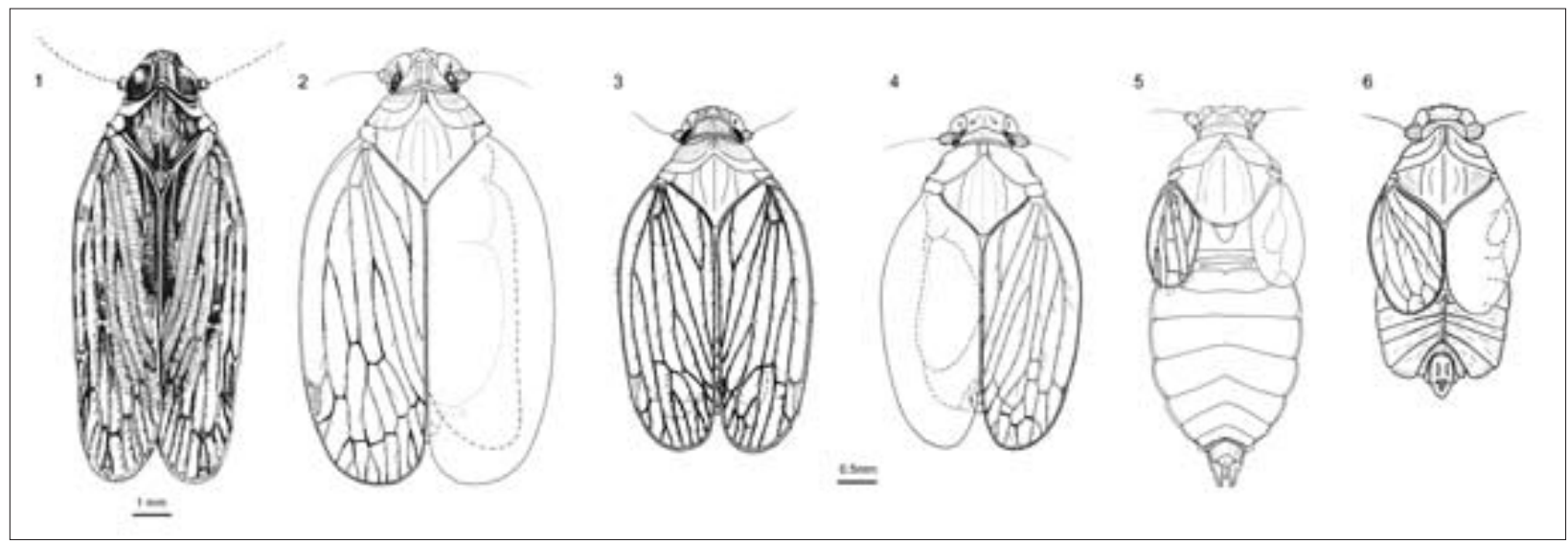

Fig. 3: Hawai'ian Oliarus species, habitus, dorsal view. 1, epigean Oliarus species (O. tamehameha); 2, O. kalaupapae; 3, O. lorettae; 4, O. gagnei; 5, O. waikau; 6. O. polyphemus. (1, from Zimmermann 1948; 2-5, from Hoch \& Howarth 1999; 6, Hoch, Original). 


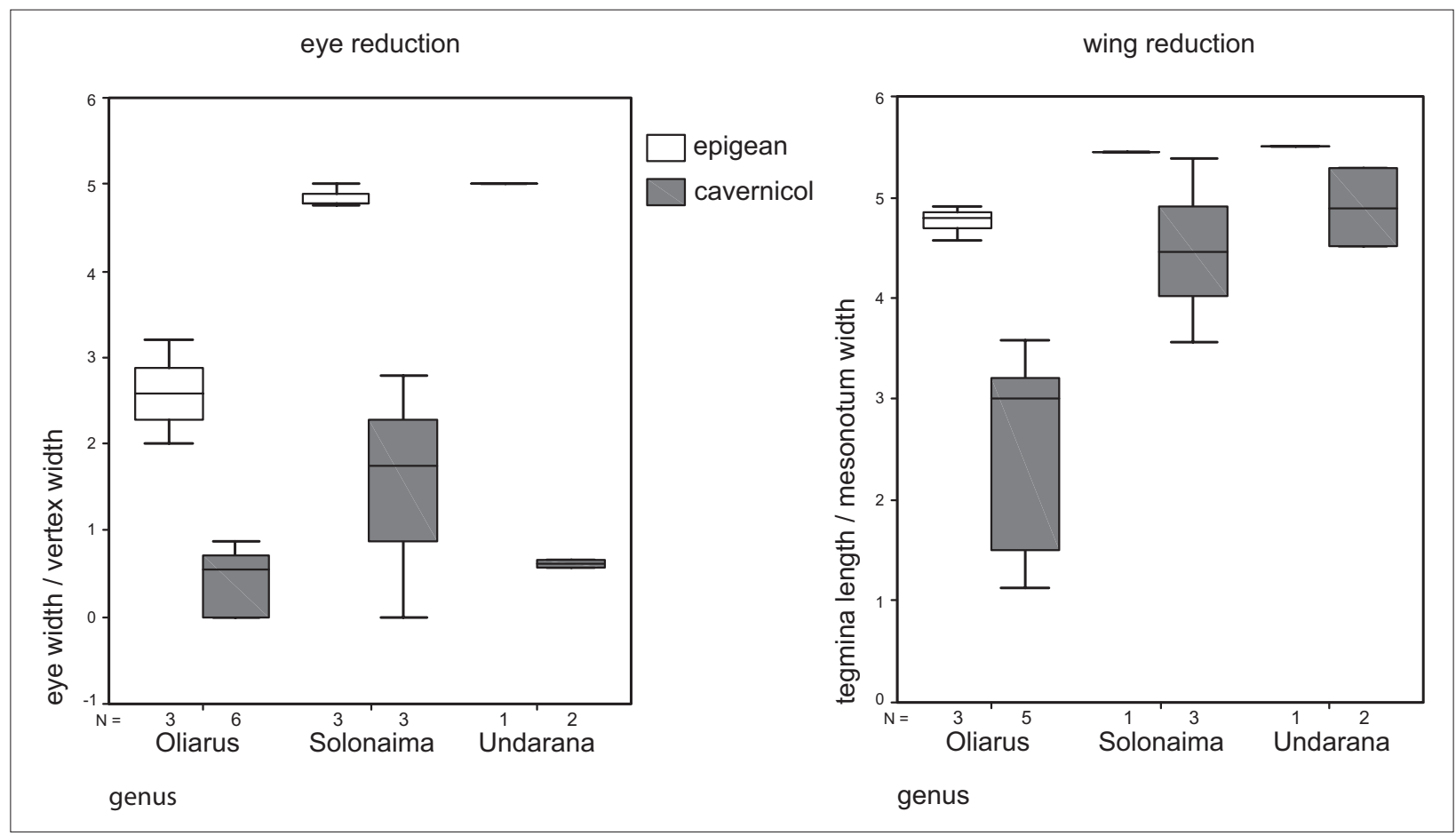

Fig. 4: Variability of relative eye width and relative tegmina length in epigean and cave-dwelling species (O. polyphemus, O. lorettae, O. makaiki (no wing measurements), O. gagnei, O. waikau, O. kalaupapae; S. pholetor (stonei), S. irvini (halos), S. baylissa; U. collina, U. rosella).

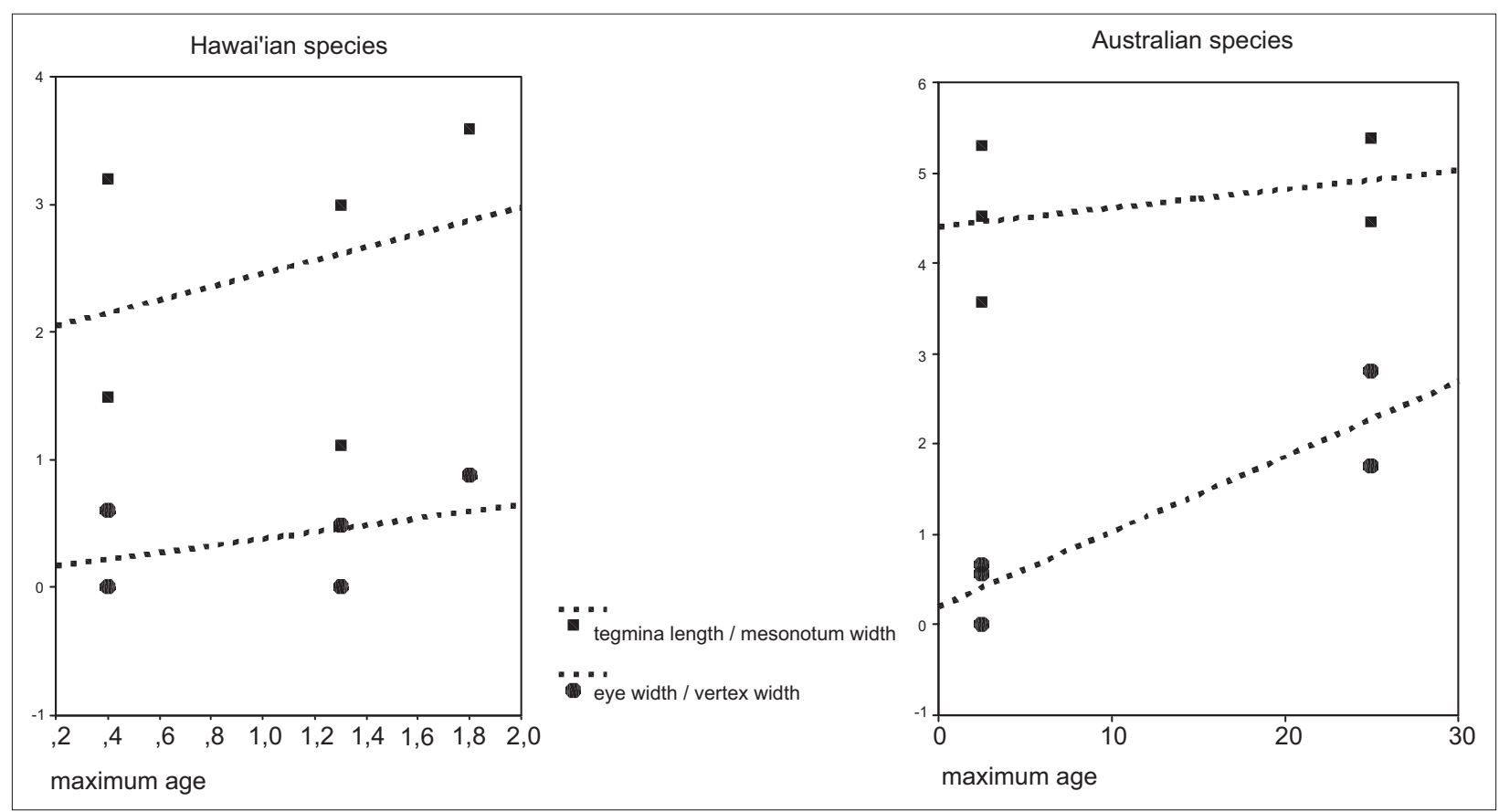

Fig. 5: Correlation of indices for troglomorphic characters with the maximum age of inhabited cave formations (O. polyphemus, O. lorettae, O. gagnei, O. waikau, O. kalaupapae; S. pholetor (stonei), S. irvini (halos), S. baylissa; U. collina, U.

trends (troglomorphies) or regressive evolution. A major obstacle in this context is the poor comparability of characters across different taxonomic groups. A strict approach should aim at analyzing character evolution in monophyletic groups where similar (morphological) pre-conditions or pre-adaptations for parallel evolution 
may safely be assumed. While we are aware of these problems, we nevertheless found it useful to employ a quantification of troglomorphic characters in order to achieve at least a preliminary idea of the possible correlation between troglomorphy and lineage age. We computed two 'troglomorphy indices' for all Hawaiian and Australian taxa from which data were available by using two characteristic troglomorphic characters in cavernicolous planthoppers: the reduction of eyes and the reduction of the tegmina. Eye reduction is apparently coupled with an obvious broadening of the vertex (see Fig. 2), so the index eye diameter: vertex width gives a clear statistical signal, ranging from 2-5 in epigean species with fully developed eyes to 0 in eyeless species. For the second index relative tegmina length we computed the absolute tegmina length: mesonotum width. Values ranges from 4.6-5.5 in epigean and from 1.1 to 5.3 in facultative and obligatory cavernicolous species.

The conspicuous differences between epigean and cave-dwelling species are clearly reflected in both indices (Fig. 4). If the data are plotted against the maximum age of the cave species, the a priori expectation is a clear negative correlation, at least for the Hawaiian taxa: the oldest cave lineages should exhibit the highest degree of troglomorphy. In contrast, we surprisingly found a weak (not significant) positive trend (Fig. 5). The same unexpected trends are seen in the Australian planthopper species.

Our results presented here, although preliminary, do not provide any evidence for cave-adaptation as a gradual orthogenetic process. Instead, we rather postulate that founder effects indeed play an important role in the origin of cave species. A correlation of the observed trends with particular ecological parameters of the cave environment cannot be excluded based on our data, but clearly this hypothesis needs further testing, especially in respect to selection pressures exerted by the conditions in high stress environments (such as caves) (Hoch \& Howarth 1989b, Howarth 1993). We can conclude with some certainty, however, that even in closely related species the degree of troglomorphy cannot be employed to infer the phylogenetic age of the cave lineages.

\section{ACKNOWLEDGEMENTS}

We thank Dr. Thomas von Rintelen, Museum für Naturkunde der Humboldt-Universität zu Berlin, for helpful discussions and many useful suggestions.

\section{REFERENCES}

Asche, M., 1997: A review of the systematics of Hawaiian planthoppers (Hemiptera: Fulgoroidea). - Pac. Sci., 51(4), 366-376, Honolulu.

Atkinson, A., Griffin, T. J. \& Stephenson, P. J., 1976: A major lava tube system from Undara volcano, North Queensland. - Bull. Volcanol., 39(2), 1-28, Napoli.

Barr, T. C., 1968: Cave ecology and the evolution of troglobites. - Evol. Biol., 2, 35-102, Amsterdam.

Barr, T. C. \& Holsinger, J. R., 1985: Speciation in cave faunas. - Ann. Rev. Ecol. Syst., 16, 313-337, Palo Alto.

Best, J. G., 1983: 1:250,000 geological series, explanation notes. $2^{\text {nd }}$ printing. - Geological Survey of Queensland, p. 36, Atherton, Qld.

Carson, H. L., 1968: The population flush and its genetic consequences. In: Lewontin, R. C., ed.: Population biology and evolution. - Syracuse University Press, 123-137, Syracuse, NY.

Carson, H. L., 1975: The genetics of speciation at the diploid level. - Am. Nat., 109, 83-92, Chicago.
Culver, D. C., 1982: Cave life. Evolution and ecology. Harvard University Press, p. 190, Cambridge, MA.

Darwin, C. R., 1859: On the origin of species by means of natural selection, or the preservation of favoured races in the struggle for life. - John Murray, p. 502, London.

Fennah, R. G., 1973: The cavernicolous fauna of Hawaiian lava tubes, 4. Two new blind Oliarus (Fulgoroidea: Cixiidae). - Pac. Ins., 15, 181-184, Honolulu.

Ford, T. D., 1978: Chillagoe - a tower karst in decay. Trans. Brit. Cave Res. Assoc., 5(2), 61-84, Bridgewater.

Hoch, H., 1994: Homoptera (Auchenorrhyncha, Fulgoroidea). In: Juberthie, C. \& Decu, V., eds.: Encyclopaedia Biospeologica. Tome I. - Société de Biospéologie, 313-325, Moulis-Bucarest. 
Hoch, H., 2002: Hidden from the light of day: planthoppers in subterranean habitats (Hemiptera: Auchenorrhyncha: Fulgoromorpha). In: Holzinger, W. \& Gusenleitner, F., eds.: Zikaden. Leafhoppers, planthoppers and cicadas (Insecta: Hemiptera: Auchenorrhyncha). (Denisia 4) - Oberösterreichisches Landesmuseum, 139-146, Linz.

Hoch, H. \& Howarth, F. G., 1989a: Reductive evolutionary trends in two new cavernicolous species of a new Australian cixiid genus (Homoptera Fulgoroidea). Syst. Entomol., 14, 179-196, Oxford.

Hoch, H. \& Howarth, F. G., 1989b: Six new cavernicolous cixiid planthoppers in the genus Solonaima from Australia (Homoptera Fulgoroidea). - Syst. Entomol., 14, 377-402, Oxford.

Hoch, H. \& Howarth, F. G., 1993: Evolutionary dynamics of behavioral divergence among populations of the Hawaiian cave-dwelling planthopper Oliarus polyphemus (Homoptera: Fulgoroidea: Cixiidae). - Pac. Sci., 47, 303-318, Honolulu.

Hoch, H. \& Howarth, F. G., 1999: Multiple cave invasions by species of the planthopper genus Oliarus in $\mathrm{Ha}-$ waii (Homoptera: Fulgoroidea: Cixiidae). - Zool. J. Linn. Soc., 127, 453-475, Oxford.

Hoch, H., Asche, M., Burwell, C., Monteith, G. M. \& Wessel, A., 2006: Morphological alteration in response to endogean habitat and ant association in two new planthopper species from New Caledonia (Hemiptera: Auchenorrhyncha: Fulgoromorpha: Delphacidae). - J. Nat. Hist., 40(32-34), 1867-1886, London.

Hoch, H. \& Wessel, A., 2006: Communication by substrate-borne vibrations in cave planthoppers. In: Drosopoulos, S. \& Claridge, M. F., eds.: Insect sounds and communication. Physiology, behaviour, ecology and evolution. - CRC-Taylor \& Francis, 187-197, Boca Raton, London, New York.

Howarth, F. G., 1972: Cavernicoles in lava tubes on the Island of Hawaii. - Science, 175, 325-326, Washington, DC.

Howarth, F. G., 1981: Non-relictual troglobites in the tropical Hawaiian caves. - Proc. $8 \mathrm{t}^{\mathrm{h}}$ Int. Cong. Speleol., 539-541, Bowling Green.

Howarth, F. G., 1986: The tropical cave environment and the evolution of troglobites. - Proc. $9^{\text {th }}$ Cong. Int. Speleol., 2, 153-155, Barcelona.

Howarth, F. G., 1987: The evolution of non-relictual tropical troglobites. - Int. J. Speleol., 16, 1-16, Bologna.

Howarth, F. G., 1988: Environmental ecology of North Queensland Caves: Why there are so many troglobites in Australia. - The $17^{\text {th }}$ Australian Speleological Federation Biennial Conference, TROPICON, 77 84, Lake Tinaroo, Far North Queensland, Australia.
Howarth, F. G., 1993: High-stress subterranean habitats and evolutionary change in cave-inhabiting arthropods. - Amer. Nat., 142(Suppl.), 65-77, Chicago.

Howarth, F. G. \& Hoch, H., 2005: Adaptive shifts. In: Culver, D. C. \& White, W. B., eds.: Encyclopedia of caves. - Elsevier Academic Press, 17-24, Amsterdam.

Jennings, J. N., 1982: Karst of northeastern Queensland reconsidered. - Tower Karst, 4, 13-52, Chillagoe.

Kemp, E. M., 1978: Tertiary climatic and vegetation history of the Southeast Indian Ocean region. - Palaeogeography, Palaeoclimatology, Palaeoecology, 24, 169-208, Amsterdam.

Mayr, E., 1954: Change of genetic environment and evolution. In: Huxley, J., Hardy, A. C. \& Ford, E. B., eds.: Evolution as a process. - Allen \& Unwin, 157-180, London.

Pearson, L. M., 1982: Chillagoe Karst solution and weathering. - Tower Karst, 4, 58-70, Chillagoe.

Remane, R. \& Hoch, H., 1988: Cave-dwelling Fulgoroidea (Homoptera Auchenorrhyncha) from the Canary Islands. - J. Nat. Hist., 22, 403-412, London.

Sbordoni, V., 1982: Advances in speciation of cave animals. In: Barigozzi, C., ed.: Mechanisms of speciation. - Liss, 219-240, New York.

Sket, B., 1986: Why all cave animals do not look alike - A discussion on adaptive value of reduction processes. - NSS Bulletin, 47, 78-85, Huntsville.

Stone, F. D., 2004: Blattodea in the genus Nocticola from Australian cave \& surface habitats. In: LaSalle, J., Patten, M. \& Zalucki, M., eds.: Entomology - Strength in Diversity. (XXII International Congress of Entomology, Brisbane 2004) - Austr. Entomol. Soc., S14W66 (abstract on CD-ROM), Brisbane.

Truswell, E. M., 1990: Australian rainforests: the 100 million year record. In: Webb, L. J. \& Kikkawa, J., eds.: Australian tropical rainforests: science, values, meanings. - CSIRO, 7-22, Melbourne.

Weismann, A., 1886: Ueber den Rückschritt in der Natur. - Ber. Naturforsch. Ges. Freiburg i. Br., 2, 1-30, Freiburg/Br.

Wilkens, H., 1986: The tempo of regressive evolution: Studies of the eye reduction in stygobiont fishes and decapod crustaceans of the Gulf Coast and west Atlantic region. - Stygol., 2, 130-143, Leiden.

Zimmerman, E. C., 1948: Insects of Hawaii. A manual of the insects of the Hawaiian Islands, including an enumeration of the species and notes on their origin, distribution, hosts, parasites, etc. Vol. 4, Homoptera: Auchenorhyncha. - University of Hawaii Press, p. 268, Honolulu. 